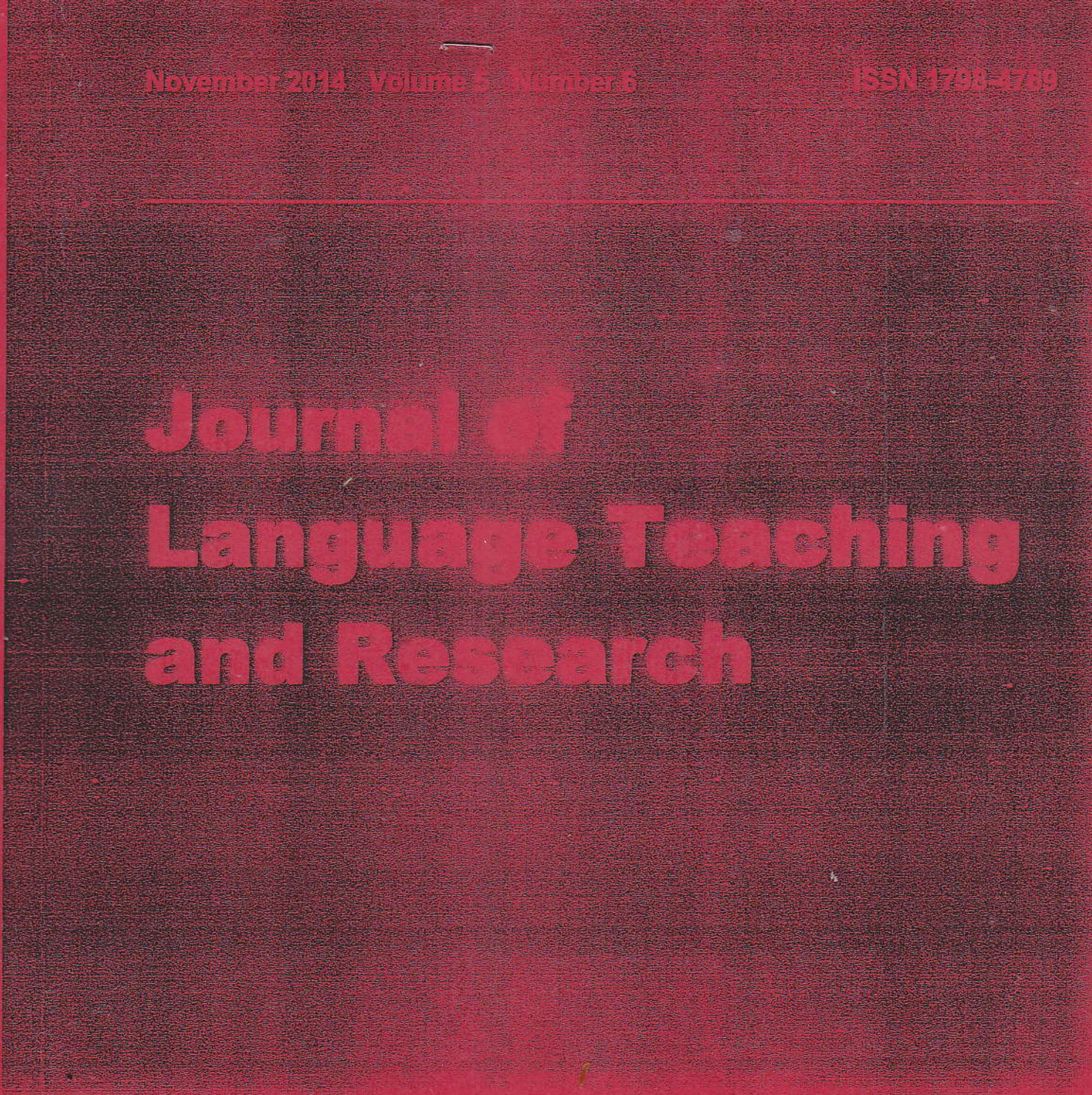




\section{Jounal of}

\section{Language Teaching. and Research}




\section{JOURNAL OF LANGUAGE TEACHING AND RESEARCH (JLTR, ISSN 1798-4769)}

\author{
Editor-in-Chief \\ Prof. Dr. María Luisa Pérez Cañado \\ Department of English Philology \\ Faculty of Humanities and Education, University of Jaén \\ Paraje Las Lagunillas, s/n 23071 Jaén, Spain
}

\author{
Managing Editor \\ Mr. Feng Liu \\ School of Foreign Languages \\ Qingdao University of Science \& Technology \\ Qingdao, China
}

\section{Editorial Board}

Dr. Airil Haimi Mohd Adnan, Universiti Teknologi MARA (UiTM), Seri Iskandar, Perak, Malaysia; Univ. of Auckland, New Zealand

Assoc. Prof. Dr. Nuray Alagözlü, Baskent University, Ankara, Turkey

Dr. Minoo Alemi, Sharif Univ. of Technology, Tehran, Iran

Dr. Mohammad Shaukat Ansari, M.L.S.M. College (L.N. Mithila University), Darbhanga, Bihar, India

Ms. Yufeng Bai, Ningbo Univ., Ningbo, China

Dr. Alexander Baratta, The Univ. of Manchester, Oxford Road, Manchester, UK

Prof. Dr. Alexander Burak, Univ. of Florida, Gainesville, FL, USA

Mr. Subhash Chandra, Centre for Development of Advance Computing (CDAC), Salt Lake City, Kolkata, India

Prof. Dr. Yuan-shan Chen, National Chin-Yi Univ. of Technology, Taiwan

Dr. Mehdi Vaez Dalili, Univ. of Isfahan, Isfahan, Iran

Prof. Qingyi Duanmu, Henan Normal Univ., Xinxiang, Henan, China

Prof. James A. Freeman, Bucks County Community College (BCCC), Newtown, PA, USA

Dr._Alexandra Galani, University of Ioannina, Greece Dr. Mahmood Hashemian, Shahrekord Univ., Shahrekord, Iran Dr. M. Athar Hussain, Sarhad Univ. of Science and Information Technology, Islamabad, Pakistan

Prof. Riyad Fayez Issa Hussein, University of Jordan, Amman, 11942, Jordan

Prof. Dr. Gale J. Isaacs, American Speech-Language-Hearing Association (ASHA); SLH in North Carolina, American Association of Univ. Professors (AAUP); Linguistic Society of America, American Association of Univ. Women (AAUW): Elizabeth City State Univ., Elizabeth City, NC, USA

Dr. Mohammad Nurul Islam, King Khalid Univ., Abha-9100. Kingdom of Saudi Arabia

Di. Ali Jahangard, Sharif Univ of Technology. Azadi Avenue Tehran, Iran

Prof. Dr. Donald Ray Jenkins, Elizabeth City State Unis

Elizabeth City, NC, USA

Prof. Dr. N. B. Jumani, International Islamic Univ., Islamabad, Pakistan

Prof. Dr. Muhammad Kamarul Kabilan, Universiti Sains Malaysia, Penang, Malaysia
Dr. Jesús García Laborda, Univ. of Alcalá at Alcalá de Henares, Madrid, Spain

Asst Prof. Dr. Hugo Y'u-Hsiu Lee, National lnstitute of Development Administration (NIDA), Bangkok, Thailand

Dr. Amerrudin b. Abd. Manan, Universiti Teknologi Malaysia, Kuala Lumpur, Malaysia

Dr. Bryan Meadows, Fairleigh Dickinson Univ., Teaneck. NJ, USA

Dr. Paula Prescod, Université de Picardie Jules Verne, Amiens, France

Mr. Haifeng Pu, Tianjin Univ. of Technology, Tianjin, China

Mr. T. Pushpanathan, SCSVMV University, Enathur, Kanchipuram - 631561, Tamilnadu, India

Dr. Xizhen Qin, Univ. of South Florida, Tampa, FL 33620, USA

Prof. Dr. Fernando Rubio, Univ. of Utah, Salt lake City, UT, USA

Dr. Mohammad Salehi, Sharif University of Technology, Tehran, Iran

Prof. Dr. Hossein Shokouhi, Deakin Univ., Melbourne Campus, Australia

Ms. Pramita Kaur Sidhu A/P Pram Singh, Kuala Lumpur Infrastructure Univ. College, Malaysia

Dr. Wichian Sittiprapaporn, Mahasarakham Univ., Khamriang, Kantharawichai, Mahasarakham 44150, Thailand Prof. Dr. Daniel J. Smith, Clemson Univ., Clemson, SC, USA

Prof. Dr. Shao-Wen Su, National Chin-Yi Univ. of Technology, Taiwan

Dr. Yousef Tahaineh, Al-Balqa' Applied Unvi., Amman. Jordan

Dr. Zia Tajeddin, Allameh Tabataba'i Univ., Tehran, Iran Prof. Dr. Eric Touya, Clemson Univ. Clemson. SC, USA Dr. Luu Trong Tuan. Open Univ., Ho Chi Minh City. Vietnam

Ms. Erxia Wang. Henan Lnix of Fmance and Economics Zhengzhou. China

Dr. Yongyang Wang, The University of Melboume, Australia Ms. Yan Zhang, Zhengzhou Institute of Aeronautical Industry Management, Zhengzhou, China

Dr. Eytan Zweig, Univ. of York, Heslington, York. UK

Joumal of Language Teaching and Research (JLTR, ISSN 1798-4769) is published bimonthly by the Academy Publisher. Post: P.O. Box 40. FIN90571, Oulu, Finland, Email: general@academvpublisher.com. Internet: http:/www academypublisher.com. Phone: $+358(0) 445257800$. Fax: - 358 (0)207 81 8199. The current and past issues are made available on-line at hitp:/www.academvpublisher.comijltr. Opinions expressed in the papers are those of the author(s) and do not necessarily express the opinions of the editors or the Academy Publisher. The papers are published as presented and without change, in the interests of timely dissemination.

c 2014 ACADEMY PUBLISHER. All rights teserved. No part of the material protected by this copyright notice mas be reproduced or utilized in any form or by any means, electronic or mechanical, including photocopying. recording or by any information storage and retrieval system. withour written permission from the copyright owner. 


\section{Journal of Language Teaching and Research}

ISSN $1798-4769$

Volume 5, Number 6, November 2014

\section{Contents}

\section{REGULAR PAPERS}

Taiwanese Graduate Students' Voices on Language Anxiety over Writing Academic Papers

Children Learning a Non-native Vowel - The Effect of a Two-day Production Training

Laura Taimi, Katri Jähi, Paavo Alku, and Maija S. Peltola

Inquiry-based Teaching in Second and Foreign Language Pedagogy

Horng-Yi Lee

Promoting Communicative Competence within EFL Contexts: A UAE Case Study

Suhair Eyad Al Alami

Types and Attributes of English Writing Errors in the EFL Context - A Study of Error Analysis

Hsiao-ping Wu and Esther V. Garza

CLT and ELT in Bangladesh: Practice and Prospect of Speaking and Listening

Marzia Shurovi

Correlation between the Tutor Competency Aspects and the Results of the Students' Basic Writing

Skills at Open University Makassar

M. Arifin Zaidin, Achmad Tolla, Muhammad Sidin Ali, and Akmal Hamsa

Reflective Thinking on EFL Classroom Discourse

Hongmei Zhu

An Inquiry into Students' Application of Metacognitive Strategies in Reading Technical Materials

Luu Hoang Mai, Luu Thi Bich Ngoc, and Tran Phuong Linh

Cultural Metaphor and Translation Strategies in English and Chinese Animal Idioms

Huiqiong Duan, Weiwei Cui, and Yidan Gao

Detecting and Correcting Unmotivated Tense Shifts by EFL English-major Jordanian Undergraduates

Maisoun I. Abu-Joudeh, Sahail M. Asassfeh, Yousef M. Al-Shaboul, and Halla A. Shureteh

An Investigation of Formulaic Sequences in Multi-modal Chinese College English Textbooks

Haiyan Miao

The Effectiveness of Stimulus to the Language Acquisition of Early Age Child

Nuraini Kasman, Syahruddin Kaseng. St. Hawang Hanafie, and Kembong Daeng

Moving forward to Communicative Proficiency: A Comparison between CET-4 Listening

Comprehension Tests and IELTS Listening Subtest

Qinglan $Y u$ and Yushan Zhao 
Translating Intangible Cultural Heritage in an Ethnolinguistic Community: A Case Study of the Site of Xanadu in Inner Mongolia

Jinyu Liu

The Impact of Immediate and Delayed Written Pushed Output Produced by Pre-intermediate EFL

Learners in Iran on Their Acquisition of English Verb Tenses

Parviz Birjandi and Homa Jafarpour Mamaghani

Gender Differences in the Undergraduates' Attitudes towards EFL

Daoshan Ma

Construct Validity of C-tests: A Factorial Approach

Ebrahim Khodadady

Women's Reconciliation with the Real World in The Good Apprentice

Mingying Xu and Guiren Shi

The Effect of Concept Mapping on Iranian Pre-intermediate L2 Reading Comprehension Omid Tabatabaei and Soghra Khalili

The Study of Non-verbal Allusion Translation in Film Subtitle: Based on Relevance Theory Juan Liu and Huijuan Jia

The Effect of Explicit Teaching of Listening Strategies and Gender on EFL Learners' IELTS

Performance

Morteza Bagheri and Samaneh Karami

Rethinking the Way Out for College English Teaching - After China's Reform in National College

Entrance Exam in English

Liu Peng, Xianjun Tan, and Fang Xie

A Study of the Sayed Ashraf-Al-Din Gilani (Nasim-e-Shomal) Poems in the Light of Frankfurt

School and Constitutional (Mashrooteh) Movement

Hamid Khanian

A Study on Designing and Evaluating Multimedia Courseware in EST Teaching

Jifeng Cao

A Review oqf the Studies on the Frequent Administrations of English Tests

Mostafa Hosseyni Ramshe

The Necessity of Comparative Ellipsis-Refuting Lechner's Claim "Comparative Ellipsis Can Be

Dispensed with"

Xiaowen Zhang

The Learner's Side of Foreign Language Learning: Predicting Language Learning Strategies from Language Learning Styles among Iranian Medical Students

Mansoor Fahim and Rezvan Noormohammadi 


\title{
Correlation between the Tutor Competency Aspects and the Results of the Students' Basic Writing Skills at Open University Makassar
}

\author{
M. Arifin Zaidin \\ Indonesian Language Education, State University of Makassar, Indonesia \\ Achmad Tolla \\ Indonesian Language Education, State University of Makassar, Indonesia \\ Muhammad Sidin Ali \\ Physical Sciences, State University of Makassar, Indonesia \\ Akmal Hamsa \\ Indonesian Language Education, State University of Makassar, Indonesia
}

\begin{abstract}
The purpose of this research was to examine the correlation between tutor competency aspects and the results of the basic writing skills for students of elementary school teacher, in particular for the distance learning Program of Open University Makassar in academic year 2012. This research was ex post facto research. It was correlation research. The populations of the research were 387 and the samples were 100 . The samples were taken by using multistage random sampling technique. The data were collected by using questionnaire and documentation study of the final semester examinations score. The data were then analyzed by using regression analysis with IBM SPSS Statistics 19 . The result of the SPSS analysis shows a simple regression. That is $\hat{\mathrm{Y}}=21,986+0,354 \mathrm{X}$. It shows that every increase for one score of tutors competency aspects $(X)$ causes the increase of 0,354 score for the results of basic writing skills $(Y)$ on constant 21,986 . Then, the value of $\mathrm{R}$ Square value obtained 0,576 . It means that $57.6 \%$ of the variation occurs on the results of the basic writing skills can be explained by variations in the tutors' competency aspects through regression equation. That is $\hat{\mathrm{Y}}=21,986+0,354 \mathrm{X}$. Results of hypothesis testing found that there is a positive and significant correlation between tutor competency aspects and the results of basic writing skills.
\end{abstract}

Index Terms - tutor competency aspect, basic writing skills, students

\section{INTRODUCTION}

Face-to-face tutorials is conducted because distance higher education students are likely to have an average midependent study (Sugilar,2000, p 187) [1] or low independent study, that is 29,8\% (Darmayanti, Islam, and ssandhimitra, 2000, p. 191) [2].

Creative and productive model Tutorial come from the targets of a strategic plan of University Open in 2010-2021 Ind the operational plan in 2010-2013. The target is the Open University should accredit tutor as much as 50\% of the hits of distance learning Programs for open universities in Indonesia.

h order to accelerate the target, in 2009 the Open University organizes a training i.e. formation of the core team for - inurs Coach [3]. In 2010, 1 Unit of distance learning Courses at the Open University of Makassar has been carrying at creative and productive model tutorials for basic writing skills course /PDGK4303. Momentum of creative and matuctive tutorial models is becoming a source of inspiration to examine more specifically whether the tutors' mptency aspects have a positive and significant correlation with the results of the basic writing skills. The purpose at this research was to examine the correlation between tutor competency aspects and the results of the basic writing I 5 for students of elementary school teacher, in particular for the distance learning Program of Open University anssar in academic year 2012. This research has two significances. They are theoretical and practical significances. The theretical significance is providing information relating to proof theory or the development of the study for the ars competency aspects and the results of basic writing skills. The practical significance is as the materials expected te input and consideration for stakeholders such as the Center for human resources development for Open University ant Istance learning Program Unit for open universities in Indonesia in order to make decision and a policy in aloping the implementation the creative and productive model for basic writing skills subject and other subjects in 


\section{A. Tutorial}

Generally, technical term "tutorials" or "tutoring" is interpreted as a guidance and learning support among friends or colleagues at peer tutoring. Concept of tutorial is also interpreted as a process when a person giving assistance and tutoring to others both individuals and groups. In this tutorial, the party who guided or assisted is called, tutee. The party who gives guiding and helping is called tutor. Both of them obtain an advantage, because either the tutor or the tutee is learning together (Tim PAU-PPAI-UT, 2001) [4].

\section{B. Tutor}

Legislation of the national education system, number 20 in 2003, article 29 paragraph: 2, mentions that tutors are professional personnel in charge of planning and implementing the process of learning, assessing learning outcomes, conducting supervision and training, as well as conducting research and devotion to the community especially for educators at College [5]. Academic tutors' qualification must be at least master's degree (S-2) in a relevant field of study and obtained from an accredited study programs (BSNP, 2007) [6]

\section{Creative and Productive}

The word of creative is English language absorption. That is "creation". Creation is an abstract noun. The adjective is "Creative" in Indonesian language being" kreatif" (Yusmansyah, 2008, p. 44-45) [7].

Ariwibowo and Roy S. (2003, p. 77) [8] describes that the creativity comes from basic words of "kreatif". It has the root of word "to create". Kaufman, J.C. (2009, p. 24) [9] explains that creativity is the interaction among the domains, the environment, and ourselves. A domain is an area of expertise that is already owned. Creativity is the core of a person's ability to create something new, either in the form of an idea or a real work which is relatively different from previously existing.

Sugono, d. (2010, p. 1103) [10] States that productive is something that is able to produce in large quantities, and also bring or giving useful results.

Productivity is related to the final result, i.e. how large the final results obtained in the production process. Determinant factors of productivity consist of knowledge, skills, abilities, and attitude. Creative and productive Model Tutorial is the right solution in basic Writing Skills tutorial because this model involves the students intellectually and emotionally in learning. In addition, it presents the opportunity to students to complete the task with responsibility and requiring hard work, dedication, enthusiasm, and confidence [11].

\section{Tutor Competency Aspects}

The term of "kompetensi" is a term derived from the English "competency" which means intelligence, and authority. In the educational context, competency is knowledge, attitudes, behaviors and skills reflected in the habit of thinking and acting. The habit of thinking which is conducted consistently and continuously allows someone to become competent in a particular field. Therefore, it can be said that an individual is considered competent if he or she has the knowledge, skills, and values that are reflected in the basic habits of thinking and acting (Harsanto, 2007, p. 130) [12].

Competency is a combination of knowledge, skills, values and attitudes which are reflected in the habit of thinking and acting. Mc Ahsan (1981: 45) (cited by Muliyasa (2004, p. 38) [13] mentions that competency is defined as the knowledge, skills and abilities possessed by someone who has been a part of him, so that he can conduct cognitive, affective, and psychomotor behavior carefully.

There are several aspects or concepts contained within the sphere of competency as follows:

a. Knowledge is the awareness in the fields of cognitive, e.g. a teacher knows how to perform the identification of bearning needs, and how to make the learning of students in accordance with their needs

b. Understanding is deepening the cognitive and affective, owned by individuals. For example, a teacher who will carry out learning must have a good understanding of the characteristics and conditions of learners, in order to carry out learning effectively and efficiently

c. Skill is something that is owned by an individual to perform a task or job that is charged. For example the ability of teachers in choosing, and making simple learning tool for the learners to provide ease of learning.

d. Value is a standard of behavior that have believed and fused in a person psychologically, for example the standard behavior of teachers in learning such as: honesty, openness, and democracy

e. Attitude is the feeling of happy-unhappy, like-dislike. It is a reaction to a stimulus that comes from the outside such as a reaction to the economic crisis, a feeling of wage increases and so on

f. Interest is the tendency of a person to commit any act, for example, interest for learning or doing something.

Spenser \& Spenser (1994) quoted Hutapea \& Thoha (2008, p. 4) [14] reveals that there are three main components of common competency, namely: knowledge owned by someone, skills, and individual behavior. Competency of tutors is an unconscious competency. It is when someone can do the job proficiently so that he can do it automatically. Competency is a set of intelligent actions, and a responsibility that belongs to a person considered as a condition for being able to perform the tasks in the community in the field of a particular work (Kepmendiknas of the Republic of Indonesia number 045/U/2002, article 1) [15]. John Stevenson (1991, p. 18) [16] mentions that the competency consists of knowledge and skills specifically in doing applied work in accordance with the requirements that have been determined. Thus, the competency owned by the tutor will show the quality of the actual tutor. The tutor must have the 
ability to compile and execute the tutorial program. Competency is the absolute requirement that should be owned by every tutor. If the tutor has no competency, the tutor may not be able to perform the duties of tutorial properly and optimally. Related to how important competencies for tutors, a Prophet Hadith narrated by Imam Bukori Shohih Bukrorinya, cited in Irfan, (2010, p. 5) [17] which means that Abu Hurayrah-Zubair said, "the Prophet said," If an affair (jobs) were handed to people who are not expert in this, then beware of the arrival time (the doomsday destruction)". This indicates that the tutors in delivering the tutorial should have competency and high professional in accordance with the field.

Based on the above description, it can be concluded that the competency is an idea of what that person does or should know in order to carry out its job properly. Competencies describe how someone is expected to behave in order to finish his work properly in accordance with the knowledge, skills, and abilities that are controlled by a part of himself. Tutor competency related to their field should have professionally because competency is a demand which has moral responsibility for the tutor.

\section{RESEARCH METHOD}

\section{A. Kind of the Research}

This research was ex post facto. It was correlation research.

\section{B. Research Design}

This research used the design of a symmetrical relationships by Rosenberg M (1968, p. 3) [18]. It was a one-way correlation consisting of one independent and dependent variable, as in the following figure:

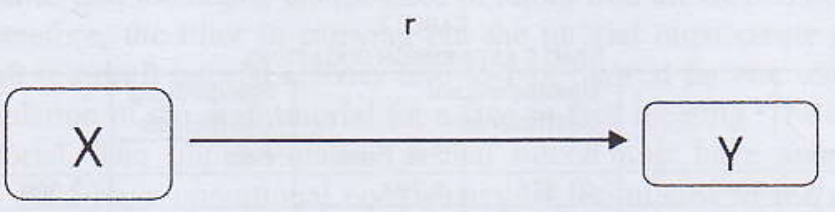

Figure 1. Research Design

Notes:

$\mathrm{X}=$ Tutor Competency

$\mathrm{Y}=$ The result of basic writing skills

$\mathrm{r}=$ Correlation

\section{Populations and Samples}

The populations in this research were 387 and the samples were 100 . The samples were taken by using multistage andom sampling technique consisting of technique of area, proportional, and random. The data were collected by using questionnaire and documentation. The questionnaire is used for assessing tutor competence aspects, while the Abcumentation is used for obtaining semester final exam score for basic writing skills subject. The samples were taken by using the following Slovin formula (Umar, 2004, p. 108) [19].

$$
\mathrm{u}=\frac{\mathrm{N}}{1+\mathrm{N}(\mathrm{e})^{2}}
$$

Notes:

$\mathrm{n}=$ Total of Samples

$\mathrm{N}=$ Total of population

$e=$ inaccuracy percent due to the looseness of sampling errors that can still be tolerated

From the inaccuracy of $10 \%$, then by using the above formula, the samples were obtained as follows:

$$
\mathrm{n}=\frac{387}{1+387(0.10)^{2}}=\frac{387}{1+4.87}=\frac{387}{4,87}=80
$$

Researchers took 100 samples, which means that they are the above of minimum desired sample by Slovin

\section{Questionnaire Testing}

Questionnaire was tested by using the advance validity test, and the expert validity test. The advance validity test shows that accuracy in measuring the indicators for each item of the instrument for tutor competency aspect is between accurate and very accurate. In addition, the validity shows that the clarity of the language used for each item of the zutors' competence is clear. The validity also shows that component charts on the instrument of tutors competency aspects are in a good category. Thus, it can be concluded that the details of these 64 instrument statements can be used to measure the aspects of tutor's competency (Azwar, 1999, p. 53) [20]. The expert validity test shows that. Assessment 
results of validator 1 and 2 toward the response to the questionnaire for the tutor's competency aspects of have high validity coefficients. That is $\mathrm{V}>0,75 \%$ (Ruslan, 2009, p. 2) [21].

Thus, the questionnaire for tutor competence aspects is reasonable to be used in this study. For more details the assessment result can be seen in the table below:

TABLE 1.

ASSESSMENT RESULT

\begin{tabular}{|l|l|l|l|}
\hline \multicolumn{4}{|c|}{ ASSESSMENT RESULT } \\
\hline & \multicolumn{3}{|c|}{ Validator I } \\
\hline Validator II & $\begin{array}{l}\text { Not Relevant } \\
\text { Score }(1-2)\end{array}$ & $\begin{array}{l}\text { Relevant } \\
\text { Score (3-4) }\end{array}$ \\
\hline & $\begin{array}{l}\text { Not Relevant } \\
\text { Score }(1-2)\end{array}$ & 1 & 1 \\
\cline { 2 - 4 } & $\begin{array}{l}\text { Relevant } \\
\text { Score (3-4) }\end{array}$ & 0 & 62 \\
\hline
\end{tabular}

\section{RESULTS AND DISCUSSION}

Research Hypothesis is that there is a correlation between the Tutors competence aspects (X) and the results of the basic writing skills (Y).

Statistical Hypothesis:

$\mathrm{H}_{0}: \rho y=0$ means that the hypothesis is rejected (not significant)

$\mathrm{H}_{1}$ : $\rho y>0$ means that hypothesis is accepted (significant)

The Result of hypothesis testing can be seen in the following table

TABLE 2

SIMPLE REGRESSION EQUATION

\begin{tabular}{|c|c|c|c|c|c|c|}
\hline \multirow{2}{*}{\multicolumn{2}{|c|}{ Model }} & \multicolumn{2}{|c|}{$\begin{array}{l}\text { Unstandardized } \\
\text { Coefficients }\end{array}$} & \multirow{2}{*}{$\begin{array}{l}\text { Standardized } \\
\text { Coefficients } \\
\text { Beta } \\
\end{array}$} & \multirow[t]{2}{*}{$\mathrm{t}$} & \multirow[t]{2}{*}{ Sig. } \\
\hline & & $\mathrm{B}$ & Std. Error & & & \\
\hline \multirow[t]{2}{*}{1} & (Constant) & -21.986 & 8.793 & & -2.500 & .014 \\
\hline & KOMP.TUTOR & .354 & .031 & .759 & 11.541 & .000 \\
\hline
\end{tabular}

Table 2 above shows that the simple regression analysis on the data of the basic writing skills score and score for data of the tutors competence aspect results in a constant " $\alpha$ " of regression coefficients 21,986 and regression coefficients "b" is 0.831 . Therefore, the equation of regression is $\hat{Y}=21,986+0,354 \mathrm{X}$. The testing found that the equation of regression is significant and linear.

The equation of regression shows that every increase of one score for tutor competency aspects (X) causes the increase of 0,354 score results of basic writing skills $(Y)$ on the constants $=21,986$ as shown in the figure 2 below:

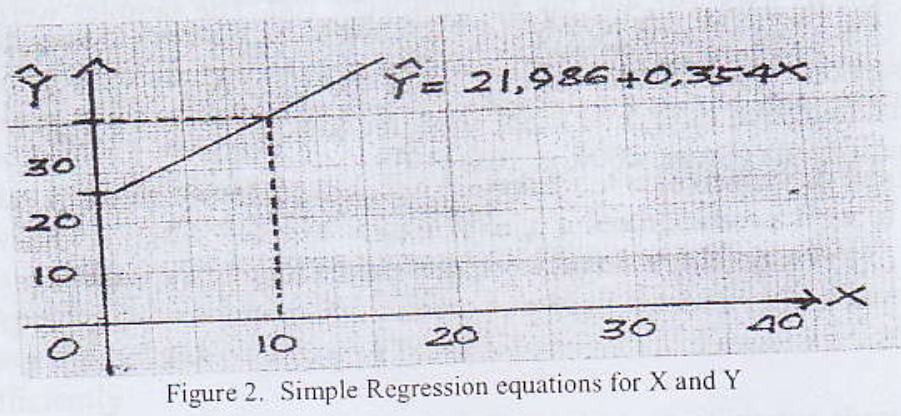

Simple correlation analysis toward the score for tutors' competence aspects $(\mathrm{X})$ and the results of the basic writing ability (Y) shows that the correlation coefficient of $r_{y 1}$ is 0,759 . Significant correlation coefficient test results by using the t-test shows that $t$ count 11,541 is significant on the significance level of 0.000 . This means that, the correlation between the tutors' competence aspect $(\mathrm{X})$ and the results of the basic writing ability $(\mathrm{Y})$ is significant.

In order to clarify the results of the analysis of the coefficient of correlation and coefficient of determination, it can be seen in the table of Model Summary ${ }^{b}$ bellow:

TABLE 3 .

MODEL SUMMARY ${ }^{H}$

\begin{tabular}{|c|c|c|c|c|c|c|c|c|c|}
\hline \multirow[b]{2}{*}{ Model } & \multirow[b]{2}{*}{$\mathrm{R}$} & \multirow[b]{2}{*}{$\begin{array}{c}\mathrm{R} \\
\text { Square } \\
\end{array}$} & \multirow[b]{2}{*}{$\begin{array}{c}\text { Adjusted R } \\
\text { Square } \\
\end{array}$} & \multirow[b]{2}{*}{$\begin{array}{l}\text { Std. Error of } \\
\text { the Estimate }\end{array}$} & \multicolumn{5}{|c|}{ Change Statistics } \\
\hline & & & & & $\begin{array}{c}\text { R Square } \\
\text { Change }\end{array}$ & F Change & dfl & $\mathrm{df} 2$ & $\begin{array}{c}\text { Sig. F } \\
\text { Change } \\
\end{array}$ \\
\hline 1 & .759 & .576 & .572 & 6.998 & .576 & 133.200 & 1 & 98 & .000 \\
\hline
\end{tabular}


Results of analysis showed that the positive correlation between aspects of tutors competence $(\mathrm{X})$ and the results of the basic writing ability $(\mathrm{Y})$ is supported by the determination of the coefficient of $\mathrm{r}_{\mathrm{yl}}{ }^{2}=0,576$. It means that $57.6 \%$ of the variations that occur in the result of basic writing skills can be explained by variations in aspects of competence of tators $(\mathrm{X})$ through the equation $\hat{\mathrm{Y}}=21,966+0,354 \mathrm{X}$

Aspect of competence of tutors consists of the ability in drawing up the draft activity tutorial, tutorial activity unit. It is also implementing the creative and productive model tutorial with a step-by-step orientation, exploration, interpretation, recreation, as well as feedback and general impression including mastery of the material, use of language, and the appearance of tutor. Tutor is one aspect of determining whether or not a tutorial is successfully. The success of the tutorial is determined by the readiness of participants in preparing a tutorial participant through the tutorial activity. If tutors have a less than optimal preparation, the tutor cannot provide optimal performance. Therefore, the competence af tutors is considered to have a positive relationship to the results of the study of basic writing skills.

Ranse \& Grealish (quoted Widhiarso, 2010, p. 3) [22] mention that competencies are divided into two types, namely personal and operational competency. The personal competency is knowledge about something, whereas operational an petency is the ability to demonstrate something practically.

Research results in Sunaryo (2004, p. 140) [23] related to the quality of the Basic Skills course tutor Writing found fut tutors are mastering the material well, excited, attentive about the success of student learning. In addition, tutors are ativering the material to be learned by answering the question of students to solve the problems faced. Another arrmon impression found is that between $95-99 \%$ of the language tutor can be followed by students well. It also found fint $75-94 \%$ tutor utterance is clear so that it is easily understood by students and the material presented stage by stage is in accordance with the order of the modules.

It suggests that the higher the competence of tutors who are owned by the tutor, the higher the results of basic writing aills of students. It is an evidence that the higher competence of tutors who are owned by the tutor, the higher the basic writing skills of students. Therefore, the tutor in carrying out the tutorial must create a design tutorial activity, and antivity unit tutorials. The draft is a draft tutorial activity face-to-face tutorial for one semester or one subject, whereas tie wit of activity is the formulation of the draft tutorial for a face-to-face meeting. The unit of activity is the reference fir tutor in carrying out tutorial. The implementation is that tutors must have appropriate personal competence atucation. Besides the tutors must have operational competency as formulated in the draft activity for creative and moductive models.

\section{CONCLUSION}

Based on the results of the research, then it can conclude that, there is a high correlation between the tutors' Brpetence aspects (X) and the results of the basic writing skills (Y) for students at the Open University of Makassar. The correlation coefficients are 0.831 . It means that competence of tutors include drafting ability activity tutorial, Incrial, activity unit the ability execute tutorial, mastery of the material, the use of proper grammar. Tutors performance s a crucial role in improving the results of basic writing skills for teacher education students for the Unit of distance leaming Programs at the Open University of Makassar.

\section{REFERENCES}

Accredited Tutors Team. (2007). The standard of Tutors qualification and competence, Jakarta: Dikti-BSNP.

Aribowo P \& Roy S. (2003). Maximize Your Strength. Tips to improve and maximize the performance, Jakarta: PT Alex Media Komputindo.

Azwar, S. (1999). Basics Psychometric, Yogyakarta : Pustaka Pelajar

A Darmayanti, T., Islam, \& Asandhimitra. (2000). Independence study on distance higher education, Distance higher education, Tim Editor: Asandhimitra dkk, Jakarta : Pusat Penerbitan Universitas Terbuka.

Departement of national education. (2010). Strategic Plan in 2010-2021, Operational Plan in 2010-2013, Jakarta: Universitas Terbuka.

Decision of the Minister of national education of the Republic of Indonesia. (2002). number 045/U/2002, about the Core Curriculum of the Directorate of higher education, article 1.

Harsanto,R. (2007). Dynamic Class management, Yogyakarta: Kanisius.

Husein, U. (2004). The method Research for thesis, 6th prints, Jakarta: PT RajaGrafindo Persada.

Inter-university Centre for the enhancement and development of instructional activities in Open University. (2001). Learning materials for the Open University Tutor Accreditation Program, Jakarta: Tim Pengembang PAT-UT.

Irfan (2010). The relationship of teacher Competence by Learning Achievements of students in the field of Hadith, Qur'an Studies, Jakarta: UIN Syarif Hidayatullah.

Kaufman, J.C. (2009). Creativity 101, Springer Publishing Company, LLC, New York.

Ministry of National Education. (2003). Legislation of the national education system, Number 20 of 2003, Jakarta: Depdiknas.

Ministry of National Education. (2005). Improving The Quality of Learning, Jakrata: Direktorat Jenderal Pendidikan Tinggi, Direktorat Pembinaan Pendidikan Tenaga Kependidikan dan Ketenagaan Perguruan Tinggi.

4) Mulyasa. (2004). Competency-based curriculum: concept, characteristics, and implementation, Bandung: PT Remaja Rosdakarya.

Rosenberg M. (1968). The Logic of Survey Analysis, New York London: Basic Book, Inc Publishers

Ruslan. (2009). Content validity, Artikel: Buletin LPMP Sulawesi Selatan "Pa'biritta", Makassar: LPMP Sulawesi Selatan. 
[17] Sugilar. (2000). Independent study Participant readiness for distance education, Jurnal: PTJJ Vol. 1 No. Tahun 2000. Jakarta: Universitas Terbuka.

[18] Sugono, D. (2011). A Dictionary of the English Language Center, Indonesia, Fourth Edition, Jakarta: PT Gramedia Pustaka Utama.

[19] Sunaryo, P.V.M. (2005). Evaluation Of The Basic Skills Tutorial Writing Undergraduate student of PGSD Open University. Jurnal Pendidikan, LPPM Universitas Terbuka.

[20] Stevenson, John. (1991). Competency Based Training in Australia: an Analysis of Assumption. Sydney: Journal the National Training Board.

[21] Thaha N.\&Hutapea P. (2008). Komptensi Plus the theory, design, cases, for HR and a dynamic Organization, Jakarta: PT Gramedia Pustaka Utama.

[22] Widhiarso, W. (2010). Kodel Validation of Competence-Based Learning, a Lecturer in Student Cantered Learning. Conference Papers: Universitas Gadjah Mada.

[23] Yusmansyah T. (2008). Aqidah Morals for Class IX Mts, Bandung: Grafindo Media Pratama.

M. Arifin Zaidin, M.Pd., was born on March 4, 1958. He is a lecturer at the Faculty of teacher training and Education Unit for distance learning Programs at the Open University of Makassar.

He graduated from the education of elementary school teacher education in 1970, Religious Education Teachers in 1974 and religious Affairs in 1976. He graduated B.a. in Indonesia language and literature faculty of teacher training, Art Literature of IKIP Ujungpandang in 1980, Bachelor's degree (S1) on Indonesian Language education in the Faculty of language and literature of IKIP Ujungpandang in 1983, Master (S2) Indonesian Language Education in postgraduate program State University of Makassar in 2000. He is now a candidate of the doctoral program State University of Makassar.

Drs. M. Arifin Zaidin, M.Pd has some scientific research and books, namely: (1) Efforts to improve the quality of implementation of the final exams of the Semester Program for elementary education distance learning Program Unit in Open University Makassar, 2010 , (2) The implementation of the basic education program Student Tutorials Tutors who Were Lecturers and Non-lecturer positions in Units of distance learning Programs Open University Makassar, 2011, (3) The relationship between Face-to-face Tutorials and the results of the final exam of the Semester Students During basic education Tutorial 2012 in distance learning Programs Unit at the Open University of Makassar, 2012, (4) Optimization and accountability Assignment in charge of the exams and the test Location, 2010, (5) Poetry and his study (book) in 2009, (6) Collection of poems "Silariang" (book) by 2010, and (7) Anthology of poetry with "rainbow of Conscience" (book) by 2010 ,

Achmad Tolla, M.Pd., was born on March 21, 1949 in Leling-Mamuju, Indonesia. He is a lecturer at the Faculty of Languages and literature at the State University of Makassar.

He graduated in elementary school Mamuju in 1965, The first State secondary school Mamuju in 1968, School of teacher education Mamuju in 1970, Bachelor's degree (S1) on The education of language and Literature of IKIP Ujungpandang in 1980, Master (S2) on Indonesian Language Education, post graduate IKIP Malang in 1991, and doctorate degree (S3) on Indonesian Language Education, UM Malang in 1996.

Prof. Dr. Achmad Tolla, M.Pd has some scientific publications, namely: (1) Shifting of languages as the result of a merging of different ethnic, in 2007, (2) Language shift in environmental migrants in Luwuk, 2004, and (3) The development of communicative language Indonesia test device for primary school Pupils in the city of Makassar, in 2003. He has been the Chairman of the Indonesian Language Education Program program studies S-2 and S-3 since 2009-present.

Muhammad Sidin Ali, M. Pd. Was born on October, 1052 in Luwu, Indonesia. He is a lecturer at the Faculty of mathematics and Natural Sciences University of Makassar.

He graduated at the Primary School in 1964, The first State secondary school in 1967, Senior High school in 1970, Bachelor's degree (S1) at IKIP Ujungpandang in 1978, Master (S2) on physics, post graduate in IKIP Yogyakarta 1985 and Doctorate degree (S3) on Educational research and Evaluation in UNJ Jakarta, 2002.

Prof. Dr. Muhammad Sidin Ali, M. Pd has some scientific publications, namely: (1) the results reviewed from several Physics Learning psychological factors (survey on Senior High School second grade Students, 2007, (2) The role of distance education in Supporting Competency Improvement Program and the qualification of teachers in 2008, (3) Research as a means of Improving teacher professional, 2013, (4) Character education through Authentic Assessment, in 2014, and (5) Relationship between attitude and motivation toward Learning Outcomes evaluation of Graduate physics education Physics Post Graduate program UNM Makassar, 2013

Akmal Hamsa, M.Pd., was born on May 2, 1955 in Sinjai, Indonesia. He is a lecturer at the Faculty of languages and literature at the State University of Makassar.

He graduated the primary school in 1968, the first Economic secondary school in 1971, State teacher education school in 1974, Bachelor's degree (S1) at IKIP Ujungpandang in 1983, Master degree (S2) on Indonesian Language in education post graduate program of IKIP Malang in 1997. Doctorate degree (S3) on Indonesian Language education in UM Malang 2009.

Dr. Akmal Hamsa, M.Pd has some scientific publications, namely: (1) Increasing Indonesian Language Teacher Professionalism, in 2009. (2) Utilization Media Audio and Images in the Expository Writing Lessons in Class VIII SMP N 21 Makassar, in 2008, and (3) studies toward the words in the Indonesian Language, in 2012. 